\title{
Analysis of the Ethical Leadership Behaviors' Effect on Life Satisfaction and Mediation Effect of Organizational Commitment
}

\author{
Zülbiye Kaçay ${ }^{1 *}$, Fikret Soyer ${ }^{2}$, Ersin Eskiler ${ }^{3}$ \\ ${ }^{1}$ Çanakkale Onsekiz Mart University, Sakarya,Turkey \\ ${ }^{2}$ Balıkesir University, Balıkesir, Turkey \\ ${ }^{3}$ Sakarya University of Applied Sciences, Sakarya, Turkey \\ *Corresponding author: zzkacay@gmail.com
}

\begin{abstract}
The aim of this study was to examine the effect of ethical leadership behaviours of school administrators on life satisfaction of physical education and sports teachers and the mediating effect of organizational commitment on this effect. For this purpose, in 2015-2016 academic year, the physical education and sport teachers working at a formal schools in different provinces of Turkey were determined as a research sample by preferring an easy sampling method, the data was obtained from a total of 436 physical education and sport teachers, (176 female and 259 male). In order to obtain data, online surveys (147) and face to face interviews (289) were used. The data obtained from the survey was analyzed by structural equation modeling method. As a result, it was determined that there was a positive relationship among ethical leadership, organizational commitment and life satisfaction. Also a partial mediating effect of organizational commitment in the relationship between ethical leadership and life satisfaction was determined.
\end{abstract}

Keywords: ethical leadership, life satisfaction, organizational commitment, physical education and sport teacher

\section{Introduction}

Human is a social being and lives his moral life individually also shapes the moral principles and values of the society by his actions. The concept of ethic, used to understand the moral life, examines and discusses the personal and social problems faced by people (Karadaş, 2014). While the leader is a person guiding and affecting people for the purpose of the organization and providing coordination (Özsalmanl, 2005), the ethical leader separates right from wrong and does the truth, looks for honesty, goodness and justice in the process of leadership and he is the role model 
who awares of his responsibilities. He uses values as a criteria in his decisions, pays attention to the perception of those around him and shows trust, respect, responsibility, fairness, and the principle of equality. Finally he integrates his skills with ethical values and reflects this to his personality, management and behaviors (Daft, 2008; Helvac1, 2010). Therefore, there is a need for an effective and ethical leadership in order to adapt to the conditions that arose as a result of the rapidly growing technological advances and globalization in every area of the society and to answer the institutions' changing needs, to be able to one step ahead. Girard (2000) as cited by Cerit, (2007) draws attention to the guidance of motivative, knowledgeable, creative, broad-minded, effective and principled leaders to deal with the problems that could be encountered in school education and management and to ensure the continuity of development in education. So, it can be said that while performing their duties, as well as laws and policies the acting of school administrators according to the principles of professional ethics is an important requirement.

Life satisfaction is a person's feeling of pleasure or unhappiness emerged as a result of positive and negative consequences of person's assessment of his own life (Shin \& Johnson, 1978; Diener, Emmons \& Griffin, 1985). As the energy of a person who enjoyed the life will reflect to his work, personal life, social relationships, shortly in all aspects of his life. In this regard, the life satisfaction can be said to be so important.

The organizational commitment is to accept the vision and objectives of an organization, and work with high energy in this direction. It is also the pleasure of being a part of the organization's members. Thus the individual, hosting the sense of belonging against the institution he worked, will serve to the purpose of the organization with a feeling of passion and responsibility and this will help him meet his needs and expectations. So it can be said that the life satisfaction, which exists as a result of a comparison of the individula's possessions and expectations will be affected in a positive way. The teachers are the greatest part of the change as they are the agents who helped the students to reach their goals and prepared them to the life. Therefore, firstly the teachers should be committed to their organizations or jobs and satisfied with their lives. This can be possibble if the manager serves according to the moral and ethical norms then, the teachers can devote themselves to their organizations and work on individual and institutional development more willingly.

In the framework of these definitions, the aim of this study was to examine the effect of ethical leadership behaviours of school administrators on life satisfaction of physical education and sports teachers and the mediating effect of organizational 
commitment on this effect. The hypothesis in accordance with determined objectives are:

$\boldsymbol{H}_{1}$ : The Ethical leadership behaviors of school principals affect the life satisfaction levels

$\boldsymbol{H}_{2}$ : The Ethical leadership behaviors of school principals affect the organizational commitment of physical education and sport teachers positively

$\boldsymbol{H}_{3}$ : The organizational commitment levels of physical education and sports teachers affect their levels of life satisfaction positively.

$\boldsymbol{H}_{4}$ : There is a mediation role of an organizational commitment between the relationship of ethical leadership behaviors of school administrators and physical education and sports teachers' life satisfaction levels.

\section{Method}

\section{Participants}

A total of 436 physical education and sports teachers, (176 female, 259 male) participated in the research. In order to obtain data, online surveys (147) and face to face interviews (289) were used. Considering the demographic characteristics of the participants, it was observed that a significant majority (48.7\%) were in 30-39 age range and it was followed by the age group respectively; 20-29 years $(28.6 \%)$ and 40 years and above (18.8\%). Income distribution of the participants: for about $1 / 2$ of them was 2,300-2,800TL (49.5\%) it was followed respectively by 2,801-3,300TL $(35.1 \%)$ and $3,301 \mathrm{TL}$ and above $(15.4 \%)$. Finally, $83.9 \%$ of participants had an undergraduate education level and $16.1 \%$ of them postgraduate.

\section{Data collection tools}

The survey technique was preferred. Ethical Leadership Scale by Y1lmaz (2006), Organizational Commitment Scale by Allen and Meyer (1990) and Life Satisfaction Scale by Diener et al. (1985) was used. Possible responses were arranged through five-item Likert-scale. In addition, to have information about socio-demographic characteristics of physical education and sports teachers, personal information form was used.

\section{Data collection process}


The research sample was determined by using an easy sampling method among physical education and sport teachers working in formal schools in different provinces of Turkey, in 2015-2016 academic year. In the process of data collection, in order to reach an adaquate number of sample online survey and face to face interview was preferred. Total of 44 survey could not be taken into consideration for various reasons.

\section{Statistical Analysis}

Data was analyzed by using SPSS 20.0 and AMOS statistical analysis programs. In order to determine whether research data obtained had a normal distiribution or not, Skewness and Kurtosis values were examined. Because values which was belong to each statement was in \pm 2 value range, the data can be said to have a normal distribution (George and Mallery, 2001).

In order to statistically test the measuring instruments whether they adapted to the known size or not, confirmatory factor analysis (CFA) was conducted for all variables. After examining the modification values suggested by the program, necessary modifications was made. It can be stated that after the modifications regression coefficients of all statements contained in the measurement tools were significant at a level of $p<0,05$ and each statement was represented by a sufficiently high coefficient. The fit index values obtained as a result of CFI was summarized in Table 1.

\section{Table 1}

The Compliance Index Values Regarding Scale Sizes

\begin{tabular}{lcccccc}
\hline & $\boldsymbol{\chi}^{\mathbf{2} / \mathbf{d f}}$ & GFI & AGFI & TLI & CFI & RMSEA \\
\hline Communicational Ethics & 3,254 & 0,917 & 0,886 & 0,959 & 0,966 & 0,072 \\
Climatic Ethics & 2,229 & 0,961 & 0,940 & 0,980 & 0,984 & 0,053 \\
Ethic in Decision Making & 3,095 & 0,966 & 0,935 & 0,969 & 0,979 & 0,069 \\
Behavioral Ethics & 3,060 & 0,963 & 0,932 & 0,977 & 0,985 & 0,069 \\
Affective Commitment & 2,928 & 0,987 & 0,954 & 0,969 & 0,987 & 0,067 \\
Continued Commitment & 2,411 & 0,989 & 0,962 & 0,971 & 0,988 & 0,057 \\
Normative Commitment & 2,298 & 0,989 & 0,967 & 0,976 & 0,989 & 0,055 \\
Life Satisfaction & 0,720 & 0,997 & 0,990 & 1 & 1 & 0,001 \\
Acceptable compliance & $\leq 5$ & $\geq 0,8$ & $\geq 0,8$ & $\geq 0,9$ & $\geq 0,9$ & $\leq 0,08$ \\
values & & & & & & \\
\hline
\end{tabular}

After determining that the compliance values obtained from CFA was at an acceptable level, the analysis of reliability and validity for each structure was 
performed. Firsly, in order to determine the validity, discrimination validity was tested through free models and the models restricted in DFA (Bagozzi, Yi \& Phillips, 1991).

\section{Table 2}

Discrimination Validity Results

\begin{tabular}{lcc}
\hline \multicolumn{1}{c}{ Models } & $\boldsymbol{\chi}^{\mathbf{2}}$ & Sd \\
\hline Restricted Model & 5252,137 & 2127 \\
Unrestricted Model & 5216,461 & 2124 \\
$\Delta \chi^{2}$ & $\mathbf{3 5 , 6 7 6}$ & \\
$\Delta$ df & & $\mathbf{3}$ \\
\hline & $3 \chi^{\mathbf{2}, 05=\mathbf{7 . 8 1 5}}$ & \\
\hline
\end{tabular}

Because ${ }_{3} \chi^{2}, 05=7,815$ and 35,676>7,815, as shown in Table 2, the structures in the model were different from eachothers. It was possible to say that the distinctive validity was provided for related model.

According to Hair, Black, Babin, \& Anderson,(2009), to demonstrate the validity of resemblance (the relationship between the structures that the statements were related) value of $\mathrm{CR}$ and AVE could be used. In order to ensure the validity of resemblance it was required that $A V E$ value shall be higher than 0.5 (AVE>0.5) and also $C R$ ratio higher than AVE (CR>AVE). When examining the values related with structures, it was seen that $\mathrm{CR}$ values was greater than AVE in each structure and AVE values of structures except for organizational commitment variables was higher than 0.5 (Table 3). In this case, it can be said that the resemblance validity for ethical leadership behaviors and life satisfaction dimensions was provided. On the other hand, it is seen for the values of organizational commitment that, in contrast to the proposed values, AVE value was less than 0.5 and CR values was higher than the values of AVE. However, in cases where other safety measure was satisfying, having a value of AVE less than 0.5 was an acceptable by various researchers (Fornell \& Larcker, 1981; Hair et al., 2009). Thus, as CR>AVE requirements was provided for the organizational commitment, it can be stated that resemblance validity for this structure was provided.

Table 3

Measurement Model Reliability Test Results Relating to Internal Consistency

\begin{tabular}{lllll}
\hline Dimensions & Items & CR & AVE & Cronbach's \\
\hline
\end{tabular}




\begin{tabular}{lcccc}
\hline & & & & Alpha $(\alpha)$ \\
\hline Ethical Leadership Behaviors & 44 & 0,986 & 0,619 & 0,985 \\
Organizational Commitment & 18 & 0,891 & 0,370 & 0,825 \\
Life Satisfaction & 5 & 0,899 & 0,640 & 0,897 \\
\hline
\end{tabular}

For each dimension, as shown in the table, the reliability coefficient Croanbach Alpha $(\alpha)$ and CR values were higher than the critical value 0.70 (Hair et al., 2009) and AVE value for ethical leadership behavior and life satisfaction variables was higher than the critical value 0,50 , they are also acceptable to the aforementioned. Although CR and $\alpha$ coefficients for organizational commitment variable was above the acceptable level, it was observed that AVE value was slightly less than desired level. As the reliability coefficient of CR and $\alpha$ was at a sufficient 1 evel and the condition of $\mathrm{CR}>\mathrm{AVE}$ was provided, the consistency of internal structure for all structures (reliability) can be expressed as to be provided.

\section{Results}

In order to test the first hypothesis of the study the structural equation model (SEM) was edited and shown in Figure 1. After the analysis, compliance values of the model $\left(\chi^{2} / \mathrm{df}=2,342 ; \mathrm{GFI}=, 804 ; \mathrm{AGFI}=, 799 ; \mathrm{TLI}=, 922 ; \mathrm{CFI}=, 926 ; \mathrm{RMSEA}=, 056\right)$ were found to be within the acceptable limits.

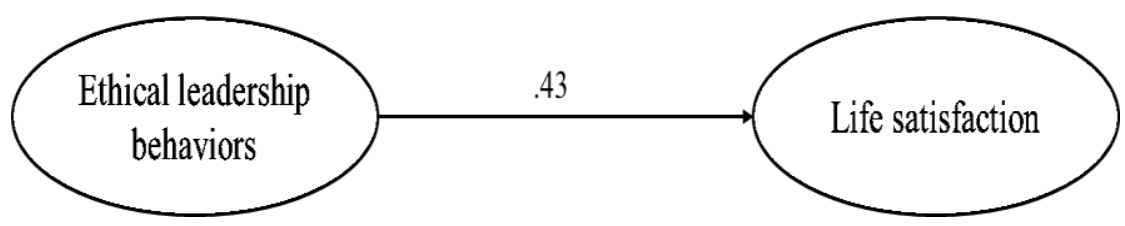

Figure 1. Structural Equation Model (SEM)

The ethical leadership behaviors of leaders was observed to have a significant effect on life satisfaction of teachers $(\beta=0.43 ; p<0.05)$. Accordingly, the first hypothesis of the study was supported. According to obtained R2 values for about $19 \%$ of the teachers' life satisfaction can be explained with the manager's ethical leadership behaviors they are responsible. 
In the relationship between ethical leadership behavior of leaders and life satisfaction, in order to determine the role of organizational commitment the second model was created and shown in Figure 2. As compliance values of the model prescribed after the analysis are not at an acceptable level, in the direction of the program proposals the modification was made and adaptation values $\left(\chi^{2} / \mathrm{df}=2,044\right.$; $\mathrm{GFI}=, 816 ; \mathrm{AGFI}=, 801 ; \mathrm{TLI}=, 933 ; \mathrm{CFI}=0.908$; $\mathrm{RMSEA}=0,049)$ was observed to be within acceptable limits.

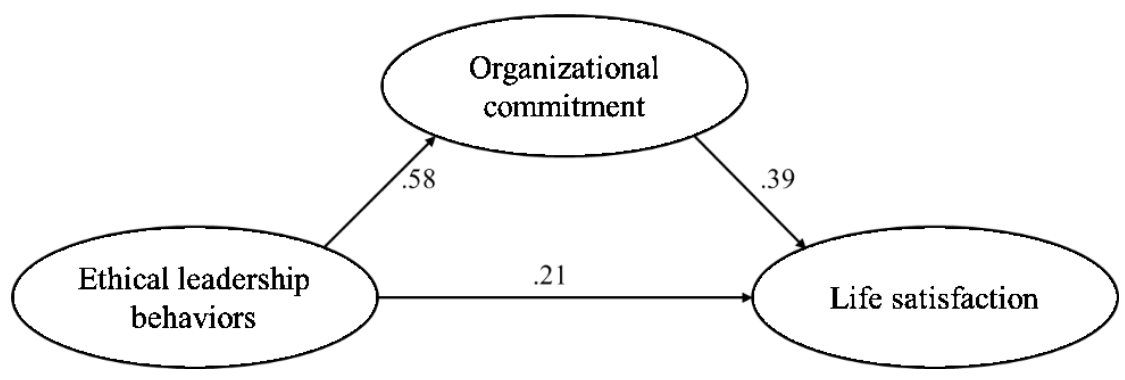

Figure 2. SEM

In the proposed model, there was a statistically significant $(\mathrm{p}<0.05)$ effect of ethical leadership behaviors of the administrators (independent variable) on organizational commitment (mediating variables); organizational commitment's (the mediating variables) on teachers' life satisfaction (dependent variable) and it was found that $\beta$ coefficient in the effect of ethical leadership behaviors of managers on life satisfaction dropped from 0.43 to 0.21 . Accordingly, the second hypothesis of the study was supported and it was possible to mention about partial mediation effect of organizational commitment on the relationship between structures.

\section{Discussion and Conclusion}

Educational management is versatile, it has two sides as theoretical and practical. Nowadays, beside the employees or managers' educational and professional qualifications, leadership and organizational capabilities began to gain importance and organizational knowledge or competence has become a general part of an education that strengthen personal and social development (Andevski, Arsenijević \& Spajić, 2012). According to Sigford (2006), an educational leader is also a manager, therefore leadership and management must work together under the guidance of a ethical leader. In this context, we can say that if the school 
administrators have a professional, organizational and an ethical leadership characteristics, educational staff can work effectively and efficiently.

In this study, school administrators' ethical leadership behaviors' effect on the physical education and sports teachers' organizational commitment and life satisfaction levels was examined also it was examined that whether organizational commitment had a mediating role on life satisfaction levels.

According to the results; ethical leadership behaviors of the managers, $(\beta=0.43$; $\mathrm{p}<0.05)$ were observed to have a significant effect on teachers' life satisfaction.

It was determined that the ethical leadership behaviors of the managers had a positive and statistically significant effect on organizational commitment (mediating variables). While Zhu, May and Avolio (2004), Neubert et al., (2009) and Kim and Brymer (2011) obtained similar results in their works; Schwepker, (2001); Cullen, Parboteeah and Victor (2003) in their researches found out that the ethical climate created in the organizations had a significant effect on the organizational commitment. In this context; the results obtained from our research and other studies in the literature supports our hypothesis and also the ethical climate conditions in the organizations created as a result of the manager behaviors affects the organizational commitment positively.

Moreover, organizational commitment has a statistically significant $(\mathrm{p}<0.05)$ effect on the teachers' life satisfaction and it was determined that $\beta$ coefficient of managers' ethical leadership behaviors' effect on life satisfaction decreased from 0.43 to 0.21 . Accordingly, the last hypothesis of the study was supported, so it is possible to mention about the partial mediating effect of the organizational commitment on the relationship between structures. Blackhurst, Brandt and Kalinkowski (1998) in their studies examined and determined that 'there is a significant relationship between career development variables and both organizational commitment and life statisfaction'. Vanaki and Vagharseyyedin (2009) in their study find out a statisticallay positive and significant relationship between organizational commitment and life satisfaction. As seen in these studies, there are many studies examined the effect of different variables on life satisfaction of the employees. However, when literature was scanned, as there are not so many studies examined whether ethical leadership had an effect on life satisfaction (Yang, 2014), our work is thought to contribute to the literature in this regard. In our study the relationships among ethical leadership, organizational commitment and life satisfaction was revealed and as a result of the ethical leadership behavior of the managers, physical education and sports teachers' life satisfaction had been seen to be affected in a positive way. According to Fullan, (2003) all kinds of leadership are aware of moral 
and ethical issues, but it can be stated that not all the leaders put into practice these issues. So the ethical leader differs from them in this regard, as he has the knowledge of moral and ethical issues as well as other characteristics of any leader and uses effectively these issues. In this context, the positive effect of ethical leadership behaviors performed by school principals can be stated to have also the positive effect on the education quality and performance of the workers in related organizations, in ongoing process. Also it was concluded that organizational commitment had a mediating effect on life satisfaction. Therefore, testing the variables, that will be effective in the structural relationship between variables, such as organizational culture, management styles, work ethic of employees, intention to leave the work and business performance, through new models to be proposed can bring a new perspective to the area. As this study was only performed on physical education and sports teachers, in order to verify the findings, conducting the research, including the different subject teachers and/or employees working in different private or public institutions, may be appropriate.

\section{References}

Allen, N. J. \& Meyer, J. P. (1990). The measurement and antecedents of affective, continuance and normative commitment to the organization. Journal of Occupational Psychology. 63, 1-18.

Altunışık, R., Coşkun, R., Bayraktaroğlu, S., \& Yıldırım, E. (2012). Research methods in social sciences: Applied SPSS. 7th Edition. Sakarya: Sakarya Bookstore.

Andevski, M., Arsenijević, J., \& Spajić, B. (2012). Leadership characteristics of employees in school systems in the Republic of Croatia and the Republic of Serbia. Hrvatski časopis za odgoj i obrazovanje, 14(4), 881-915.

Bagozzi, R. P., Yi, Y., \& Phillips, L. W. (1991). Assessing construct validity in organizational research. Administrative Science Quarterly, 421-458.

Blackhurst, A.E., Brandt, J.E., \& Kalinkowski, J. (1998). Effects of career development on the organizational commitment and life satisfaction of women student affairs administrators. NASPA Journal, 36(1), 19-34.

Cerit, Y. (2007). Implementation levels of primary school principals' service oriented leadership roles. Hacettepe University Journal of Education. 38, 88-98.

Cullen, J. B., Parboteeah, K. P., \& Victor, B. (2003). The effects of ethical climates on organizational commitment: A two-study analysis. Journal of Business Ethics, 46(2), 127-141.

Daft, L. R. (2008). The leadership experience. 4th edition. Mason, Ohio: Thomson SouthWestern

Diener, E., Emmons, R. L., Griffin, S. (1985) The satisfaction with life scale. J Pers Assess, 49: 71-75.

Fornell, C., \& Larcker, D. F. (1981). Evaluating structural equation models with unobservable variables and measurement error. Journal of Marketing Research, 18(1), 39-50. 
Fullan, M. (2003). The moral imperative of school leadership. Toronto: Ontario Principals' Council.

George, D. \& P. Mallery. (2001). SPSS for Windows step by step: A simple guide and reference 10.0 update. 3rd edition. Boston: Allyn and Bacon.

Girard, S. H. (2000). Servant leadership qualities exhibited by Illinois Public School District superintendents. Dissertation Abstracts International, 64(3).

Hair, J. F., Black, W., Babin, B., \& Anderson, R. (2009). Multivariate data analysis, upper saddle river. N.J.: Prentice Hall.

Helvac1, M. A. (2010). Ethical leadership behavior levels of school administrators. Zeitschrift für die Welt der Türken. 2(1), 391-409.

Karadaş, F. (2014). The Relationship Between Ethical Leadership Behaviors of and Motivation Levels, Unpublished Master's Thesis. Antalya: Akdeniz University.

Kim, W. G., \& Brymer, R. A. (2011). The effects of ethical leadership on manager job satisfaction, commitment, behavioral outcomes, and firm performance. International Journal of Hospitality Management, 30(4), 1020-1026.

Neubert, M. J., Carlson, D. S., Kacmar, K. M., Roberts, J. A., \& Chonko, L. B. (2009). The virtuous influence of ethical leadership behavior: Evidence from the field. Journal of Business Ethics, 90(2), 157-170.

Özsalmanlı, A.Y. (2005), “Türkiye'de Kamu Yönetiminde Liderlik ve Lider Yöneticilik”, Manas Üniversitesi Sosyal Bilimler Dergisi, Sayı:13, s. 137-146

Schwepker, C. H. (2001). Ethical climate's relationship to job satisfaction, organizational commitment, and turnover intention in the salesforce. Journal oOf Business Research, 54(1), 39-52.

Shin, D. C., \& Johnson, D. M. (1978). Avowed happiness as an overall assessment of the quality of life. Social Indicators Research, 5, 475- 492.

Sigford, J. L. (2006). The Effective School Leader's Guide to Management. California: Corwin Press.

Vanaki, Z., \& Vagharseyyedin, S. A. (2009). Organizational commitment, work environment conditions, and life satisfaction among Iranian nurses. Nursing \& Health Sciences, 11(4), 404-409.

Yang, C. (2014). Does ethical leadership lead to happy workers? A study on the impact of ethical leadership, subjective well-being, and life happiness in the Chinese culture. Journal Of Business Ethics, 123(3), 513-525.

Y1lmaz E. (2006). Investigation of organizational trust level at schools in terms of ethical leadership characteristics of school administrators and some variables. Unpublished Doctoral Dissertation. Konya: Selcuk University.

Zhu, W., May, D. R., \& Avolio, B. J. (2004) The impact of ethical leadership behavior on employee outcomes: The roles of psychological empowerment and authenticity. Journal of Leadership \& Organizational Studies, 11(1), 16-26. 